\title{
Post-Traumatic Stress Disorder in Homeless Migrant Mothers of the Paris Region Shelters
}

\author{
Mathilde Roze ${ }^{1}$, Maria Melchior ${ }^{1}$, Cécile Vuillermoz ${ }^{1}$ (), Dalila Rezzoug ${ }^{2,3}$, Thierry Baubet ${ }^{2,3}$ \\ and Stéphanie Vandentorren ${ }^{1,4, *}$ \\ 1 INSERM, Sorbonne Université, Institut Pierre Louis d'Epidémiologie et de Santé Publique (IPLESP), \\ Department of Social Epidemiology, F75012 Paris, France; mathilde.rz@gmail.com (M.R.); \\ maria.melchior@inserm.fr (M.M.); cecile.vuillermoz@inserm.fr (C.V.) \\ 2 CESP Inserm 1178, Université Paris 13, APHP Hôpital Avicenne, 93000 Bobigny, France; \\ dalila.rezzoug@aphp.fr (D.R.); thierry.baubet@aphp.fr (T.B.) \\ 3 Centre National de Ressources et Résilience, 59800 Lille, France \\ 4 Santé Publique France, French National Public Health Agency, F-94415 Saint-Maurice, France \\ * Correspondence: stephanie.vandentorren@santepubliquefrance.fr
}

Received: 30 May 2020; Accepted: 1 July 2020; Published: 7 July 2020

\begin{abstract}
Migrant women are disproportionately more likely to experience traumatic events in their country of origin, during migration and after arriving in the host country. Homeless women are more likely to be exposed to multiple victimizations in childhood (emotional or physical maltreatment) and in adulthood (sexual abuse, street victimization). This study's objective was to describe the factors associated with the likelihood of post-traumatic stress disorder (PTSD) among homeless migrant mothers in the Paris region. Face-to-face interviews were conducted by bilingual psychologists and interviewers in a representative sample of homeless families in the Paris region. PTSD was ascertained using the Mini International Neuropsychiatric Interview (MINI) $(n=691$ mothers). We studied PTSD in mothers using weighted Poisson regression. Homeless migrant mothers had high levels of PTSD $(18.9 \%)$ in the 12 months preceding the study. In multivariate analysis, PTSD was associated with departure from the country of origin because of violence ( $\mathrm{PR}=1.4595 \% \mathrm{CI} 1.03 ; 2.04)$, depression in the preceding 12 months ( $\mathrm{PR}=1.8295 \% \mathrm{CI} 1.20 ; 2.76)$, and residential instability ( $\mathrm{PR}=1.9395 \% \mathrm{CI}$ $1.27 ; 2.93)$. Homeless migrant mothers have high levels of traumatic events and PTSD. Improvements in screening for depression and PTSD and access to appropriate medical care are essential for this vulnerable group.
\end{abstract}

Keywords: homeless migrants; women; PTSD; mental health

\section{Introduction}

Post-traumatic stress disorder (PTSD) is an anxiety disorder that can arise after an individual has experienced a severe traumatic event, such as the threat of injury or death (e.g., a car crash, a natural disaster, physical aggression, or rape) [1]. Symptoms include "reliving" the event with flashbacks and nightmares, avoidance with emotional numbing and feeling detached, arousal with difficulty concentrating, sleep disturbances, and outbursts of anger [2].

PTSD in homeless populations is very prevalent [3], specifically in women, with $25.7 \%$ in 123 homeless women included in the French Housing First Program [4] suffering from PTSD, versus almost 7\% in women of the overall population in France in 2003 [5]. Most studies to date have explored whether homeless people have had an elevated level of exposure to traumatic events and cumulate risk factors which brought on PTSD (e.g., witnessing or being the victim of an attack, sexual assault) [6-8], but less is known about the role of homelessness itself as a traumatic experience that leads to exposure to factors predicting PTSD. 
The number of homeless families in France has increased dramatically since 2010 due to several factors. First, the rise in poverty and the cost of living in the Paris region has increased difficulties in accessing housing, especially for the most vulnerable groups [9]. Second, the increase in the number of recent family immigrants hosted in shelters not initially intended for them has mechanically led to a higher number of homeless persons. As in many large European cities, the proportion of migrants among the homeless in Paris has increased over time (38\% in 2001, 52\% in 2012) [10]. The epidemiological evidence regarding the mental health of migrants remains sparse and findings are heterogeneous [11], with estimates of PTSD prevalence in adult refugees ranging from 4\% [12] to $68 \%$ [13]. Migrant families are disproportionately exposed to traumatic events and comprise various profiles, such as "labor migrants", "refugees", and "asylum seekers", who are particularly vulnerable to depression and PTSD [14].

First, previous studies suggest that migrants are at risk of PTSD due to a history of multiple potentially traumatic pre-migratory events $[15,16]$. Immigrant populations are more vulnerable to PTSD due to their exposure to traumatic experiences prior to migration, such as organized violence and political oppression. This is especially true for women [3]. Second, difficult post-migration living conditions put migrant families at risk of economic difficulties and social suffering in the host country [17]. Migrants' families face factors associated with mental distress after migration, such as acculturative stress arising from unfamiliarity with daily tasks, discrimination, and severe post-migration difficulties, such as delays in the processing of asylum applications involving their legal status, being relegated to the margins of society, social isolation, language barriers, cultural differences, labor rights difficulties in finding stable employment and securing stable living and housing conditions, loneliness, and health difficulties $[18,19]$.

Host countries do not take all these problems into account and in France, applying for accommodation is a complex process, particularly for immigrant families who are mobile, socially excluded, and often non-French speaking [20]. We focused on housing conditions because, first, becoming homeless can lead to trauma through the loss of stable sheltered accommodation, of connections with their family, and of social roles and routines. Second, chronic homelessness and associated stressors, such as the continuous uncertainty about where to find food and safe shelter, can erode a person's coping mechanisms [21]. Third, homelessness might be the breaking point for those who have pre-existing behavioral health conditions or a prior history of trauma [22]. Homeless migrants' families cumulate risk factors for developing PTSD that could impact physical [23] and other mental disorders (depression, anxiety disorders) [24,25] and also impact biological (cellular aging [26]) and social functioning [27].

To our knowledge, few studies have focused on housing conditions and homelessness and their relationship with mental health [28]. Most studies exploring PTSD in migrants have been conducted in the United States, where migrant families consist of poor young people from ethnic minorities with health issues [29]. Little is known about homeless migrant families with PTSD in Europe. Mothers with children on very low or no income constitute the majority of this population. We therefore aimed to (1) describe the prevalence of PTSD in homeless migrant mothers in the Paris region and (2) identify factors associated with PTSD, including living and housing conditions.

\section{Methods}

\subsection{Population Study}

The "enfants et familles sans logement" (ENFAMS; "homeless children and families") survey [20] was conducted by the Observatoire du Samu Social from January to May 2013 to estimate the number of homeless families living in sheltered accommodation in the Paris region (approximately 12 million inhabitants) and describe their sociodemographic characteristics and health. It was based on a random sample of 801 families provided with accommodation in emergency centers, long-term rehabilitation centers, social hotels, and centers for asylum seekers. Families eligible for ENFAMS were defined as 
comprising at least one parent ( $>18$ years old) with at least one child younger than 13 years, speaking one of the 17 languages of the survey, and able to provide written consent to participate.

\subsection{Survey Design}

Time-location sampling was used [30]. ENFAMS estimated that over 10,280 homeless families were living in sheltered accommodation in the Paris region, corresponding to approximately 35,000 people, including 17,660 children. The sampling process, which was detailed elsewhere [20], included three levels of random sampling: shelters (which were randomly selected among an exhaustive list of all services in the Paris region), families (which were randomly selected in each selected service; either the single parent or one of the two parents was interviewed, in $95.4 \%$ of the cases this was the mother), and one child under 13 randomly selected in each family. Families who chose not to participate in ENFAMS were characterized by younger maternal age (33 vs. 38 years), a higher proportion of men ( 15.3 vs. $4.6 \%$ among study participants), and having two or more children ( 31.7 vs. $23.1 \%$ among study participants). The reasons most frequently cited for non-participation were lack of interest $(17 \%)$, lack of time (14\%), or the other parent's lack of written consent (11\%).

\subsection{Ethics}

The ENFAMS survey design was approved by the French National Confidentiality Committee (CNIL, DR-2013-147)), and two ethics boards (the Comité de Protection des Personnes (CPP Ref 201202 06, 22/08/2012) for the greater Paris area, and the Comité Consultatif sur le Traitement de l'Information en matière de Recherche dans le domaine de la Santé (CCTIRS n_12.471, 17/09/2012)).

\subsection{Data Collection}

Survey data were collected in questionnaires during random face-to-face interviews conducted by trained interviewers and psychologists in up to 17 different languages in each shelter. For each family, the mother and one child under 13 were interviewed. Interviewing mothers was preferred when possible, given that many questions regarded very young children (e.g., breast feeding, etc.) and that they were more often present in the shelter to answer the interviewer. In our present sub-study on PTSD, we only analyzed mothers' questionnaires (fathers only accounted for $4 \%$ of interviewed parents).

\subsection{Variables Used}

Outcome. Traumatic events were assessed using the following question: "Have you experienced a terrible, frightening, or horrible event at some point in your life that caused you to have distressing memories or nightmares, to feel isolated or distant from others, to have difficulty sleeping or concentrating, or to be excessively nervous?". Only mothers who reported experiencing at least one traumatic event answered subsequent questions on PTSD symptoms.

PTSD (lifetime and previous 12 months) was ascertained by the PTSD module of the Mini International Neuropsychiatric Interview (MINI). The MINI is a brief structured diagnostic interview for major psychiatric disorders and generates reliable and valid psychiatric diagnoses [31,32]. Thus, the outcome of this study was "to suffer from PTSD in the 12 months preceding the study" (measured by the MINI) (yes/no).

Explanatory Variables. Factors examined as potentially associated with PTSD risk according to our analysis of the literature review included:

Sociodemographic characteristics: age; region of birth; family status (i.e., living with a partner, number of children, and their age); legal resident status; employment status; education level; typical monthly income (poverty line $=964$ euros/month/UC); health insurance status (dichotomized into "full health insurance" (which included social security cover, voluntary insurance, and free healthcare for persons on low income) and "partial health insurance" (which included social security cover only or partially payable healthcare for persons on low income); proficiency in French (no difficulties to 
understand, to speak, to read, or to write); migratory trajectory (i.e., reason for departure from country of origin and time since family's arrival in France).

Health: food insecurity in the preceding 12 months (assessed using the French version of the US Household Food Security Module [33,34]); self-reported health (very good, good, or fair physical health vs. poor or very poor health); serious health problem(s) disrupting daily life; anemia (ascertained by blood samples collected by study nurses); body mass index (BMI) (anthropometric measures taken by study nurses); pregnancy; female circumcision; major depression (ascertained using the Composite International Diagnostic Interview (CIDI) [35], and suicide risk (ascertained using the Mini International Neuropsychiatric Interview (MINI) [36,37]).

Living and housing conditions: previously spent at least one night on the street; type of shelter ("short-term" for social hotels or emergency shelters and "long-term" for housing facilities for asylum seekers and long-term re-habilitation centers); housing quality (i.e., number of persons per room); residential instability (i.e., less than 6 months in a current shelter); lack of social support (i.e., knowing no one living in France at the time of their arrival); help from non-governmental organizations (NGOs), friends, or family (i.e., obtaining a food voucher, luncheon voucher, food parcel, clothes, or money from these people and organizations).

\subsection{Statistical Analysis}

Our analysis was based on a sample of 691 mothers with complete PTSD data who were not born in France. Missing data were imputed (max $7.73 \%$ of missing data for health insurance status). The first step of the analysis consisted of a description of the distribution of PTSD by factors identified in our literature analysis using Chi-squared tests, using a count of those with PTSD against those with no PTSD. Second, to identify characteristics associated with PTSD in the study sample, we used a weighted Poisson regression with robust error variance [38], which provided prevalence ratios (PR) and $95 \%$ confidence intervals (95\% CI). Third, all the variables significantly associated with PTSD in univariate analyses $(p<0.05)$ were included in the multivariate analysis.

All statistical analyses were performed with R software (version 3.2.0 using the "survey" weighting package and "mice" package to impute missing data).

\section{Results}

\subsection{Study Population Characteristics}

Median age at the time of the study was 31.0 years (Q1 27.0-Q3 36.0), 54.2\% were born in Sub-Saharan Africa, $13.8 \%$ in North Africa, and $15.8 \%$ in Eastern Europe (Figure 1).

More than half were single mothers (53.1\%), 19.2\% were employed or in education, and $38.0 \%$ were proficient French speakers. Most families (98.3\%) had an income below the poverty level (964 euros/month/UC), $22.2 \%$ had no health insurance, and $53.7 \%$ suffered from food insecurity. Sociodemographic characteristics for our study sample of homeless migrant mothers are shown in Table 1.

Among the study population, $62.4 \%$ reported traumatic events and $16.2 \%$ had PTSD in the preceding 12 months ( $23.6 \%$ lifetime). Mothers born in Central Africa had a higher number of traumatic lifetime events (Figure 2), half of them having experienced at least four such events. $75 \%$ of mothers from Central Africa had experienced more than one traumatic event (first quartile), 50\% more than four (median), and $25 \%$ more than six (third quartile).

The distribution of traumatic events among homeless migrant mothers with PTSD is shown in Table 2, 80.5\% experienced the unexpected or sudden death of an intimate friend or family member, while $48.7 \%$ witnessed someone being injured or dying. 
Table 1. Sociodemographic characteristics of homeless migrant mothers in the Paris region (ENFAMS survey 2013, $n=691)$.

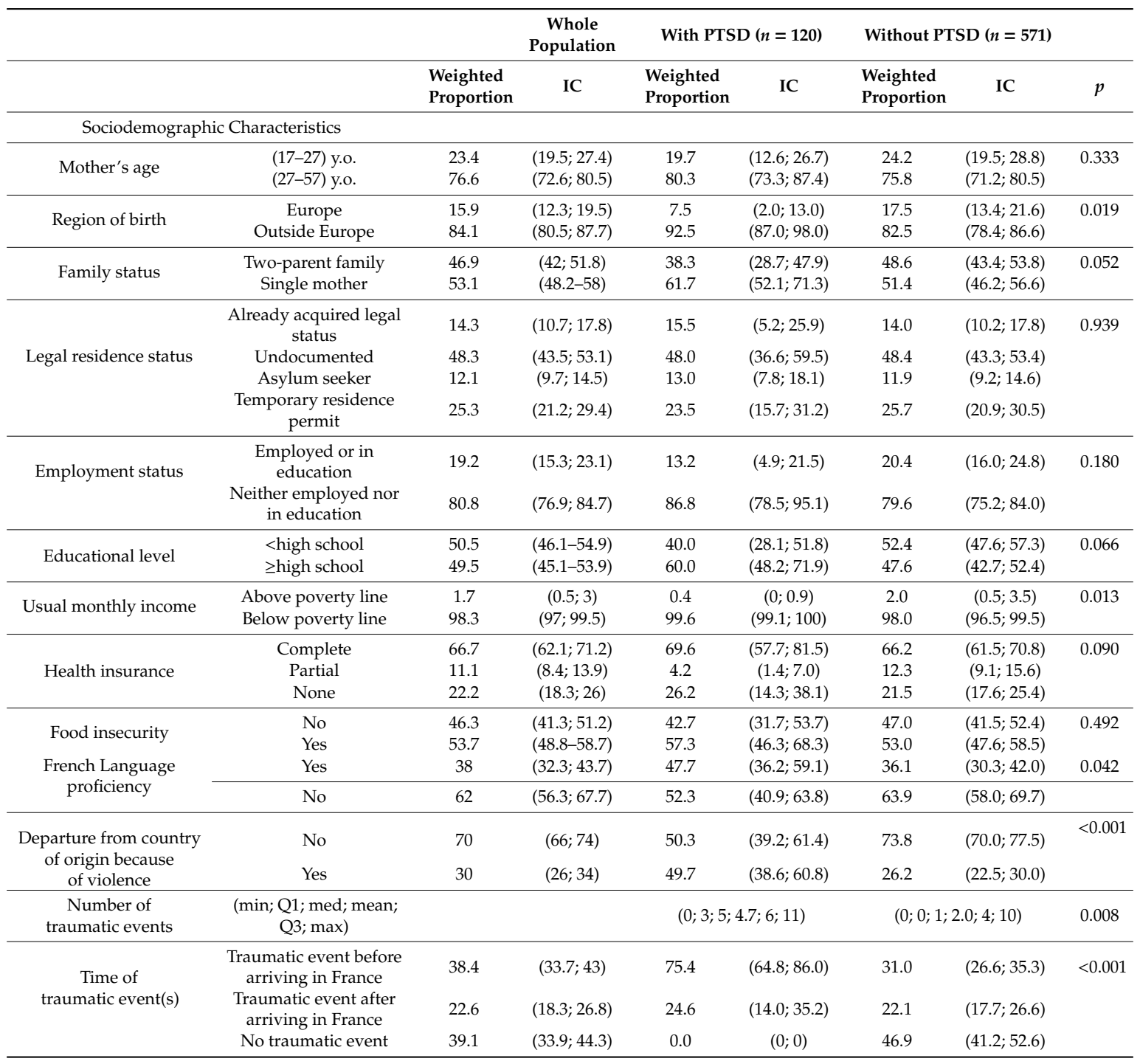

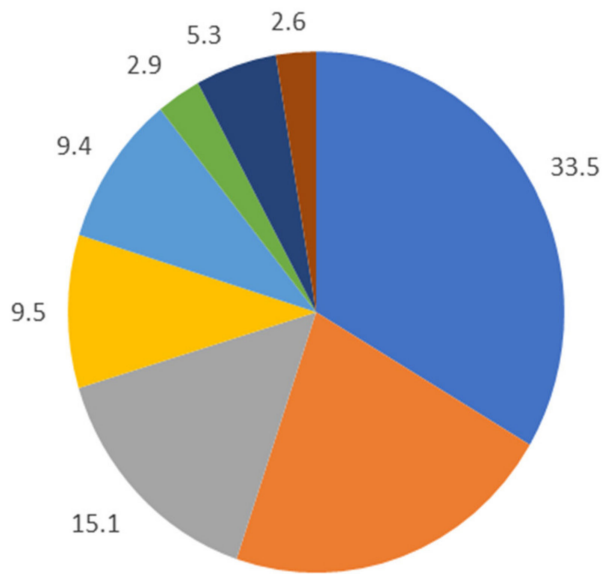

21.7
- Western Africa (33.5\%)

- Central Africa (21.7\%)

m Eastern Europe (15.1\%)

n Northern Africa (9.5\%)

- Western Asia (9.4\%)

- Eastern Africa (2.9\%)

- Rest of Asia (5.3\%)

- Other $(2.6 \%)$

Figure 1. Country of origin of migrant homeless mothers in the Paris region (The "enfants et familles sans logement" (ENFAMS; "homeless children and families") survey 2013, $n=691$ ). 


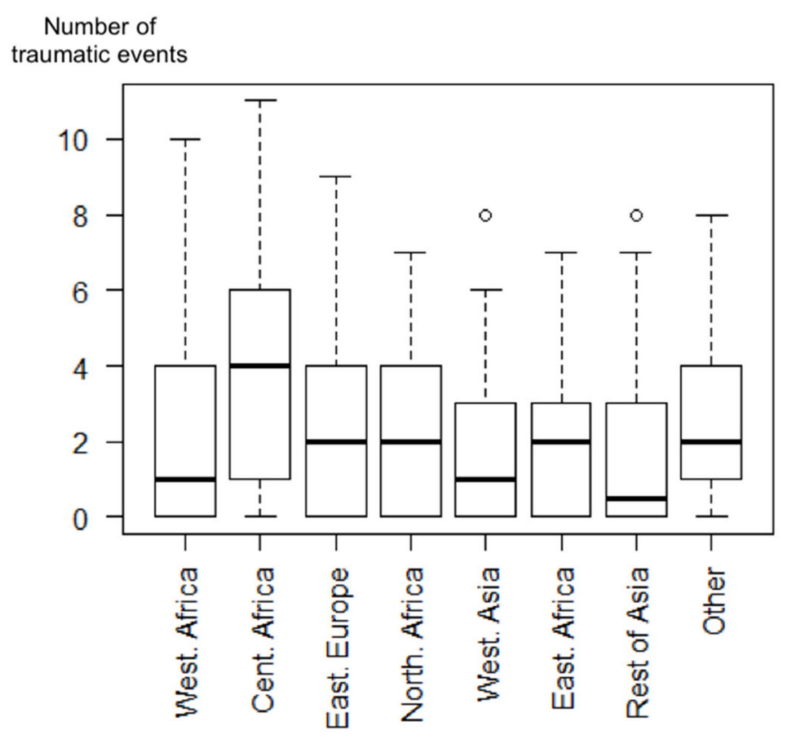

Figure 2. Boxplot representing the number of traumatic lifetime events according to the country of origin among migrant homeless mothers in the Paris region (ENFAMS survey 2013, $n=691$ ).

Table 2. Traumatic lifetime events in homeless migrant mothers who suffered from Post-traumatic stress disorder (PTSD) in the last 12 months, Paris region (ENFAMS survey 2013, $n=120$ ).

\begin{tabular}{cc}
\hline Traumatic Lifetime Events & Women with PTSD ( $\boldsymbol{n = 1 4 9 )} \%$ \\
\hline Unexpected or sudden death of an intimate friend or a member of family & 80.5 \\
Witnessing someone get injured or dying & 48.7 \\
Experienced a wartime event & 38.4 \\
Victim of assault by a close relative & 37.6 \\
Accident or life-threatening illness & 36.1 \\
Victim of rape or sexual assault & 35.9 \\
Victim of torture or kidnapping & 33.6 \\
Discovery of a corpse & 29.0 \\
Victim of burglary or armed robbery & 25.6 \\
Earthquake, landslide, hurricane & 18.9 \\
Other disasters including fires, flooding & 13.2 \\
Victim of physical assault in the course of work & 8.8 \\
Illness of an intimate friend or family member & 4.7 \\
Responsible for injury or death of another person & 3.2 \\
Exposure to radiation or other dangerous substances & 1.4 \\
\hline
\end{tabular}

The majority of these women declared a good perceived health (88.3\%), 25.5\% were anemic, $36.6 \%$ were obese, and $7.8 \%$ were pregnant at the time of the study (Table 3). In terms of mental health, $16.9 \%$ were at risk of suicide and $27.4 \%$ had experienced depression.

Over fourteen percent (14.6\%) had previously spent at least one night on the street. The median time since arrival in France was 2.7 years (Q1 1.4-Q3 5.6), 20.8\% were housed in a long-term shelter, and $37.1 \%$ experienced residential instability. Over half (58.2\%) did not know anyone in France when they arrived or knew someone but he/she had not helped. Finally, $27.4 \%$ had received no assistance whatsoever (from social security, friends, etc.). 
Table 3. Health characteristics and living conditions of homeless migrant mothers in the Paris region (ENFAMS survey 2013, $n=691$ ).

\begin{tabular}{|c|c|c|c|c|c|c|c|c|}
\hline \multirow[t]{2}{*}{$\begin{array}{l}\text { Health Characteristics } \\
\text { and Living Conditions }\end{array}$} & & \multicolumn{2}{|l|}{$\begin{array}{l}\text { Whole } \\
\text { Population }\end{array}$} & \multicolumn{2}{|c|}{ With PTSD $(n=120)$} & \multicolumn{2}{|c|}{$\begin{array}{l}\text { Without PTSD } \\
\quad(n=571)\end{array}$} & \multirow[b]{2}{*}{$p$} \\
\hline & & $\begin{array}{l}\text { Weighted } \\
\text { Proportion }\end{array}$ & IC & $\begin{array}{l}\text { Weighted } \\
\text { Proportion }\end{array}$ & IC & $\begin{array}{l}\text { Weighted } \\
\text { Proportion }\end{array}$ & IC & \\
\hline \multicolumn{9}{|c|}{ Health Characteristics } \\
\hline \multirow{2}{*}{$\begin{array}{l}\text { Perceived current } \\
\text { general state of health }\end{array}$} & $\begin{array}{l}\text { Very good, good or fair } \\
\text { global health }\end{array}$ & 88.3 & $(85.4 ; 91.2)$ & 74.7 & $(63.3 ; 86.1)$ & 91,0 & $(88.4 ; 93.5)$ & $<0.001$ \\
\hline & $\begin{array}{l}\text { Poor or very poor } \\
\text { global health }\end{array}$ & 11.7 & $(8.8 ; 14.6)$ & 25.3 & $(13.9 ; 36.7)$ & 9,0 & $(6.5 ; 11.6)$ & \\
\hline \multirow{2}{*}{$\begin{array}{l}\text { Serious health } \\
\text { problem }(\mathrm{s})\end{array}$} & No & 71.3 & $(66.8 ; 75.8)$ & 59.4 & $(47.9 ; 70.9)$ & 73,6 & $(69.1 ; 78.1)$ & 0.012 \\
\hline & Yes & 28.7 & $(24.2 ; 33.2)$ & 40.6 & $(29.1 ; 52.1)$ & 26,4 & $(21.9 ; 30.9)$ & \\
\hline \multirow{2}{*}{$\begin{array}{l}\text { Pregnant (at time of } \\
\text { survey) }\end{array}$} & No & 92.2 & $(90 ; 94.3)$ & 84.7 & $(77.2 ; 92.2)$ & 93,6 & $(91.6 ; 95.6)$ & 0.003 \\
\hline & Yes & 7.8 & $(5.7 ; 10)$ & 15.3 & $(7.8 ; 22.8)$ & 6,4 & $(4.4 ; 8.4)$ & \\
\hline \multirow{2}{*}{ Female circumcision } & No & 79.3 & $(75.4 ; 83.1)$ & 81.6 & $(73.2 ; 90.1)$ & 78,8 & $(74.5 ; 83.1)$ & 0.584 \\
\hline & Yes & 20.7 & $(16.9 ; 24.6)$ & 18.4 & $(9.9 ; 26.8)$ & 21,2 & $(16.9 ; 25.5)$ & \\
\hline \multirow{2}{*}{ Suicide risk } & No & 83.1 & $(79.7 ; 86.5)$ & 62.5 & $(52.1 ; 72.9)$ & 87,1 & $(83.7 ; 90.5)$ & $<0.001$ \\
\hline & Yes & 16.9 & $(13.5 ; 20.3)$ & 37.5 & $(27.1 ; 47.9)$ & 12,9 & $(9.5 ; 16.3)$ & \\
\hline \multirow{2}{*}{$\begin{array}{l}\text { Depression in the } \\
\text { previous } 12 \text { months }\end{array}$} & No & 72.6 & $(68.7 ; 76.5)$ & 40.3 & $(28.1 ; 52.6)$ & 78,8 & $(74.7 ; 83.0)$ & $<0.001$ \\
\hline & Yes & 27.4 & $(23.5 ; 31.3)$ & 59.7 & $(47.4 ; 71.9)$ & 21,2 & $(17.0 ; 25.3)$ & \\
\hline \multicolumn{9}{|c|}{ Living Conditions } \\
\hline \multirow{2}{*}{$\begin{array}{l}\text { Previously spent at least } \\
\text { one night on the street }\end{array}$} & No & 85.4 & $(82.6 ; 88.3)$ & 73.4 & $(64.4 ; 82.4)$ & 87,8 & $(84.8 ; 90.7)$ & $<0.001$ \\
\hline & Yes & 14.6 & $(11.7 ; 17.4)$ & 26.6 & $(17.6 ; 35.6)$ & 12,2 & $(9.3 ; 15.2)$ & \\
\hline \multirow{2}{*}{$\begin{array}{l}\text { Time since arrival } \\
\text { in France }\end{array}$} & $>1$ year & 85.3 & $(82.5 ; 88)$ & 84.8 & $(77.9 ; 91.6)$ & 85,4 & $(82.5 ; 88.3)$ & 0.864 \\
\hline & $\leq 1$ year & 14.7 & $(12 ; 17.5)$ & 15.2 & $(8.4 ; 22.1)$ & 14,6 & $(11.7 ; 17.5)$ & \\
\hline \multirow{2}{*}{ Type of shelter } & Short-term shelter & 79.2 & $(75.5 ; 83)$ & 71.2 & $(61.7 ; 80.7)$ & 80,8 & $(77.0 ; 84.5)$ & 0.031 \\
\hline & Long-term shelter & 20.8 & $(17 ; 24.5)$ & 28.8 & $(19.3 ; 38.3)$ & 19,2 & $(15.5 ; 23)$ & \\
\hline \multirow{2}{*}{$\begin{array}{l}\text { Number of persons } \\
\text { per room }\end{array}$} & $\leq 2$ pers per room & 42.1 & $(36.5 ; 47.7)$ & 44.4 & $(33.8 ; 55.0)$ & 41,6 & $(35.8 ; 47.5)$ & 0.613 \\
\hline & $>2$ pers per room & 57.9 & $(52.3 ; 63.5)$ & 55.6 & $(45.0 ; 66.2)$ & 58,4 & $(52.5 ; 64.2)$ & \\
\hline \multirow{2}{*}{ Residential instability } & No & 62.9 & $(58.2 ; 67.6)$ & 42.3 & $(31.6 ; 52.9)$ & 66,9 & $(61.7 ; 72.2)$ & $<0.001$ \\
\hline & Yes & 37.1 & $(32.4 ; 41.8)$ & 57.7 & $(47.1 ; 68.4)$ & 33,1 & $(27.8 ; 38.3)$ & \\
\hline \multirow{2}{*}{$\begin{array}{l}\text { Already knew someone } \\
\text { who lived in France, } \\
\text { and this person helped }\end{array}$} & $\begin{array}{c}\text { Yes, and he/she } \\
\text { was helpful }\end{array}$ & 41.8 & $(37.2 ; 46.4)$ & 28.6 & $(18.2 ; 39.0)$ & 44,3 & $(39.4 ; 49.3)$ & 0.013 \\
\hline & $\begin{array}{c}\text { No, I did not know } \\
\text { anyone or yes, but } \\
\text { he/she was not helpful }\end{array}$ & 58.2 & $(53.6 ; 62.8)$ & 71.4 & $(61.0 ; 81.8)$ & 55,7 & $(50.7 ; 60.6)$ & \\
\hline \multirow{2}{*}{$\begin{array}{l}\text { Help from association, } \\
\text { friends or family }\end{array}$} & Yes & 72.6 & $(68.3 ; 76.9)$ & 69.1 & $(58.6 ; 79.5)$ & 73,2 & $(68.6 ; 77.9)$ & 0.454 \\
\hline & No & 27.4 & $(23.1 ; 31.7)$ & 30.9 & $(20.5 ; 41.4)$ & 26,8 & $(22.1 ; 31.4)$ & \\
\hline
\end{tabular}

\subsection{Factors Identified as Associated with PTSD}

All characteristics in Table 1 were tested for their association with PTSD. Table 3 shows only factors associated with PTSD in migrant mothers: being born outside of Europe (PR $=2.3495 \% \mathrm{CI}$ 1.10; 4.97); low monthly income (PR $=4.0495 \%$ CI 1.14; 14.31); not being a proficient French speaker $(\mathrm{PR}=0.6795 \% \mathrm{CI} 0.46 ; 0.98)$; departure from the country of origin because of violence $(\mathrm{PR}=2.2895 \%$ CI 1.57; 3.30); number of traumatic events ( $\mathrm{PR}=1.3495 \%$ CI $1.27 ; 1.42)$; poor self-reported health ( $\mathrm{PR}=$ $2.5795 \%$ CI 1.61; 4.11); having serious health problems ( $\mathrm{PR}=1.6995 \%$ CI 1.12; 2.55); pregnant at the time of study (PR $=2.1395 \%$ CI 1.34; 3.38); suicide risk and depression (respectively, $\mathrm{PR}=2.9695 \% \mathrm{CI}$ 2.04; 4.29 and $\mathrm{PR}=3.8395 \% \mathrm{CI} 2.42 ; 6.08$ ); having previously spent at least one night on the street $(\mathrm{PR}=2.0995 \% \mathrm{CI} 1.40 ; 3.12)$; long-term shelter ( $\mathrm{PR}=1.5495 \% \mathrm{CI} 1.05 ; 2.27)$; residential instability ( $\mathrm{PR}=2.32$ 95\% CI 1.54; 3.49 for mothers who had spent less than 6 months in their current shelter); and lack of social support (PR $=1.7995 \%$ CI $1.13 ; 2.84)$.

\subsection{Multivariate Analysis}

In the multivariate analysis (Table 4), after adjusting for age, factors associated with PTSD in the study sample included departure from the country of origin because of violence ( $\mathrm{PR}=1.4595 \% \mathrm{CI} 1.03$; 2.04), depression in the preceding 12 months ( $P R=1.8295 \% \mathrm{CI} 1.20 ; 2.76)$, and residential instability $(\mathrm{PR}=1.93$ 95\% CI 1.27; 2.93). 
Table 4. Characteristics associated with PTSD in the last 12 months in homeless migrant mothers in the Paris region (ENFAMS survey 2013, $n=691$, univariate and multivariate Poisson regression analyses).

\begin{tabular}{|c|c|c|c|c|c|c|c|}
\hline & \multirow[t]{2}{*}{ Characteristics } & \multirow[b]{2}{*}{$\begin{array}{l}\text { Weighted } \\
\text { Proportion }\end{array}$} & \multicolumn{3}{|c|}{ Univariate Analysis } & \multicolumn{2}{|c|}{$\begin{array}{l}\text { Multivariate } \\
\text { Analysis }\end{array}$} \\
\hline & & & $\begin{array}{c}\text { PTSD } \\
\text { Prevalence }\end{array}$ & PR & IC & PR & IC \\
\hline \multicolumn{8}{|c|}{ Socio-Demographic Characteristics } \\
\hline \multirow{2}{*}{ Mother's age } & (17-27) yo & 23.4 & 13.6 & - & & & \\
\hline & $(27-57)$ yo & 76.6 & 17.0 & 1.25 & $(0.79 ; 1.98)$ & & \\
\hline \multirow{2}{*}{ Country of birth } & Europe & 15.9 & 7.6 & ref & & & \\
\hline & Outside Europe & 84.1 & 17.8 & 2.34 & $(1.10 ; 4.97)$ & & \\
\hline \multirow{2}{*}{ Typical monthly income } & Above poverty line & 1.7 & 4.1 & - & & & \\
\hline & Below poverty line & 98.3 & 16.4 & 4.04 & $\begin{array}{l}(1.14 ; \\
14.31)\end{array}$ & & \\
\hline Proficiency in & Yes & 38.0 & 20.3 & - & & & \\
\hline French language & No & 62.0 & 13.7 & 0.67 & $(0.46 ; 0.98)$ & & \\
\hline \multirow{2}{*}{$\begin{array}{l}\text { Departure from country } \\
\text { of origin because }\end{array}$} & No & 69.8 & 11.7 & - & & ref & \\
\hline & Yes & 30.2 & 26.6 & 2.28 & $(1.57 ; 3.30)$ & 1.45 & $(1.03 ; 2.04)$ \\
\hline $\begin{array}{c}\text { Number of traumatic } \\
\text { events }\end{array}$ & $\begin{array}{c}\text { (min; Q1; med; mean; Q3; } \\
\text { max) }\end{array}$ & \multicolumn{2}{|c|}{$(0 ; 0 ; 1 ; 2.2 ; 4 ; 11)$} & 1.34 & $(1.27 ; 1.42)$ & & \\
\hline \multirow{2}{*}{$\begin{array}{l}\text { Time of traumatic event } \\
\text { (TE) }\end{array}$} & $\begin{array}{l}\text { TE before arrival in } \\
\text { France }\end{array}$ & 39.0 & 31.3 & - & & & \\
\hline & TE after arrival in France & 23.2 & 17.2 & 0,55 & $(0.34 ; 0.88)$ & & \\
\hline \multicolumn{8}{|c|}{ Health Characteristics } \\
\hline \multirow{2}{*}{$\begin{array}{l}\text { Perceived current general } \\
\text { state of health }\end{array}$} & $\begin{array}{l}\text { Very good, good or fair } \\
\text { global health }\end{array}$ & 88.4 & 13.7 & - & & & \\
\hline & $\begin{array}{c}\text { Poor or very poor global } \\
\text { health }\end{array}$ & 11.6 & 35.2 & 2.57 & $(1.61 ; 4.11)$ & & \\
\hline \multirow{2}{*}{ Serious health problem(s) } & No & 71.2 & $13 . .5$ & - & & & \\
\hline & Yes & 28.8 & 22.8 & 1,69 & $(1.12 ; 2.55)$ & & \\
\hline \multirow{2}{*}{ Pregnant at time of study } & No & 92.2 & 14.9 & - & & & \\
\hline & Yes & 7.8 & 31.7 & 2,13 & $(1.34 ; 3.38]$ & & \\
\hline \multirow{2}{*}{ Suicide risk } & No & 83.1 & 12.2 & - & & & \\
\hline & Yes & 16.9 & 36.0 & 2,96 & $(2.04 ; 4.29)$ & & \\
\hline \multirow{2}{*}{$\begin{array}{l}\text { Depression in the } \\
\text { previous } 12 \text { months }\end{array}$} & No & 72.7 & 9.1 & - & & & \\
\hline & Yes & 27.3 & 35.0 & 3.83 & $(2.42 ; 6.08)$ & 1.82 & $(1.20 ; 2.76)$ \\
\hline \multicolumn{8}{|c|}{ Living Conditions } \\
\hline \multirow{2}{*}{$\begin{array}{l}\text { Previously spent at least } \\
\text { one night on the street }\end{array}$} & No & 85.3 & 13.9 & - & & & \\
\hline & Yes & 14.7 & 29.1 & 2.09 & $(1.40 ; 3.12)$ & & \\
\hline \multirow{2}{*}{ Type of shelter } & Short-term shelter & 79.2 & 14.5 & - & & & \\
\hline & Long-term shelter & 20.8 & 22.4 & 1.54 & $(1.05 ; 2.27)$ & & \\
\hline \multirow{2}{*}{ Residential instability } & No & 62.9 & 10.9 & - & & ref & \\
\hline & Yes & 37.1 & 25.2 & 2.32 & $(1.54 ; 3.49)$ & 1.93 & $(1.27 ; 2.93)$ \\
\hline \multirow{2}{*}{$\begin{array}{l}\text { Already knew someone } \\
\text { who lived in France, and } \\
\text { he/she helped }\end{array}$} & $\begin{array}{l}\text { Yes, and he/she was } \\
\text { helpful }\end{array}$ & 41.9 & 11.1 & - & & & \\
\hline & $\begin{array}{l}\text { No, I did not know } \\
\text { anyone or yes, but he/she } \\
\text { was not helpful }\end{array}$ & 58.1 & 19.8 & 1.79 & $(1.13 ; 2.84)$ & & \\
\hline
\end{tabular}

\section{Discussion}

In our study, homeless migrant mothers reported high levels of traumatic events (62.4\%) and PTSD. Specifically, $23.6 \%$ and $16.2 \%$, respectively, met the lifetime and previous 12 months criteria for PTSD diagnosis. Departure from the country of origin because of violence $(P R=1.45)$ was associated with suffering from PTSD in the last 12 months. Additionally, PTSD was associated with depression in the preceding 12 months ( $\mathrm{PR}=1.82$ ), highlighting the role of overall psychological vulnerability. Finally, post-traumatic experiences also appeared to play a role: residential instability $(\mathrm{PR}=1.93)$ was associated with PTSD. Our results highlight that migrant homeless mothers accumulate stress from multiple factors, which translates into a very high, and often undetected, prevalence of PTSD.

PTSD prevalence in migrants ranges between 4 [11] and 68\% [12] depending on the context and specific population under study. In a previous study [39], $42.6 \%$ and $29.7 \%$ of homeless mothers in 
three U.S. cities met, respectively, the lifetime and previous 12 months criteria for PTSD. Those results are consistent with ours (respectively, $23.6 \%$ and $16.2 \%$ ). Previous studies on the French general population in 2001-2003 indicated that prevalence of lifetime PTSD was 3.9\% and PTSD in last year was $2.2 \%$ [40].

Prior studies also found similar prevalence levels to ours with regard to traumatic events $(75 \%$ to $84.15 \%)[13,16]$. In our study, traumatic events reported by participating mothers were especially violent: $80.5 \%$ had experienced the unexpected or sudden death of an intimate friend or family member, $48.7 \%$ had witnessed someone being injured or dying, 38.4\% had experienced war, 37.6\% were victims of assault by a close relative, and $35.9 \%$ were victims of rape or sexual assault. To these traumatic events, we can add having spent at least one night on the street $(14.6 \%)$.

Furthermore, $35.9 \%$ of our study sample were survivors of rape or sexual assault. It is important to note the growing amount of literature documenting the association between mothers' mental health and children's emotional difficulties [41], highlighting the importance of maternal PTSD on their offspring.

In our study, PTSD was associated with depression. Debate surrounds the question of whether it is sensible to distinguish these two diagnoses in the aftermath of trauma [42]. More specifically, some studies suggest that depression is a risk factor of PTSD, and reciprocally, that PTSD is a risk factor of depression [43], and that the two disorders represent an underlying joint vulnerability. Because our data were cross-sectional, we are not in a position to contribute to this debate. However, our results highlight a high prevalence of PTSD among migrant mothers who are psychologically vulnerable.

The post-traumatic experiences associated with PTSD in our study, such as housing accommodation and low income, are consistent with prior research. Porter and Haslam [44] found that housing accommodation and restricted economic opportunities moderated mental health outcomes, regardless of resettlement location. Several studies in the Netherlands [45] found that financial difficulties, daily stress, and immigration status [46] were associated with PTSD symptoms. In our study, living and housing conditions (residential instability), were associated with PTSD.

Social support acts as a protective factor and a buffer against the impact of traumatic events [47,48]. However vulnerable people do not usually ask for help. Our study shows that receiving assistance from an NGO, friends, or family was not associated with PTSD. However, knowing someone in France who helped the participant upon their arrival was associated with lower levels of PTSD. Other factors, such as marital status [49], French language proficiency [46], and time since arrival in France [50,51] — which may act as proxies for time since exposure to trauma—were not associated with PTSD.

Chronic PTSD could increase the risk of women's other mental and physical health problems but also could deteriorate social functioning and impact the nearby environment and the child. Some studies demonstrated that maternal PTSD may be associated with negative child behavior outcomes (externalizing, internalizing, and emotion regulation) [52,53]. This relation could be explained because parents' PTSD can impact the functioning of parenting (lower parenting satisfaction, less optimal parent-child relationships, and more frequent use of negative parenting practices, such as overt hostility and controlling behaviors [54]). In this context, it is necessary to develop interventions which help migrant women with PTSD, especially since some studies showed that patients with a migratory background did not benefit from psychotherapy as much as patients without a migratory background [55].

The study has several limitations. First, the ENFAMS survey was cross-sectional in nature and consequently had an exploratory approach. We did not have specific data on the history of traumatic events; therefore, it is hard to determine whether they occurred prior to the departure from the country of origin, during migration, or after arrival in France. Furthermore, the direction of the association between some of the factors studied (e.g., depression) and mental health is difficult to determine. Second, population homogeneity (most families were very poor, unemployed, etc.) may explain why some factors (e.g., food insecurity and employment status) were not associated with PTSD. Third, 
our participants may have differed in terms of their sensitivity to different traumatic factors according to their socio-cultural and religious backgrounds.

Despite these limitations, our study also has strengths. First, ENFAMS included a multicultural sample of homeless families rarely studied in France. In much of the existing research on PTSD, study participants are limited to individuals from the same country of origin. Our present sub-study sought to fill gaps in the mental health literature in Europe, by studying PTSD prevalence among homeless migrant mothers in the Paris area, who are diverse in terms of region of origin, legal residence status, and living and housing conditions. Second, we used validated measures for mental health (MINI and CIDI) and physical health, together with a detailed questionnaire on living and housing conditions. Third, the fact that interviews were conducted by trained interviewers and psychologists in 17 different languages provides hitherto unknown data in France.

Our results stress the role of health professionals in addressing the mental health needs of this population. Serious post-migration living difficulties, including residential instability, were related to PTSD. Serious post-migration living difficulties have a re-traumatizing effect on vulnerable individuals with limited capacity to handle resettlement stress due to their previous traumatic history [56]. Policies enhancing the social protection of immigrants in a host country would be a powerful instrument to reduce the number of traumatic events, of post-migration living difficulties, and consequent post-traumatic stress disorder. For example, permanent private accommodation is associated with better outcomes and is almost always cheaper than social hotels in France. PTSD in homeless migrant mothers may not be the inevitable consequence of acute wartime stress. Other contextual factors involved in its development and progression can be effectively managed by material and non-material support from host country governments.

\section{Conclusions}

Homeless migrant women in France have high levels of traumatic events and PTSD, in part related to their departure from their country of origin because of violence, but also to their current living and housing conditions (e.g., residential instability). Improvements in the monitoring of mental health (depression and PTSD) and access to appropriate medical care for this vulnerable population could limit the impact of PTSD on their health and on that of their children.

Author Contributions: Conceptualization, S.V.; methodology, S.V., M.M.; software, M.R.; validation, S.V., M.M., T.B., and D.R.; formal analysis, M.R. and C.V., data curation, M.R.; writing-original draft preparation, M.R., S.V. and M.M.; writing-review and editing, C.V., T.B. and D.R. supervision, S.V. and M.M.; project administration, S.V. All authors have read and agreed to the published version of the manuscript.

Funding: This research received no external funding

Acknowledgments: The authors gratefully acknowledge the Observatoire of Samu Social and Bruno Falissard. They thank the interviewers and all the families involved in this study. They also thank Jude Sweeney for the English editorial assistance.

Conflicts of Interest: The authors declare no conflict of interest.

\section{References}

1. North, C.S.; Surís, A.M.; Smith, R.P.; King, R.V. The evolution of PTSD criteria across editions of DSM. Ann. Clin. Psychiatry 2016, 28, 197-208. [PubMed]

2. Gootzeit, J.; Markon, K. Factors of PTSD: Differential specificity and external correlates. Clin. Psychol. Rev. 2011, 31, 993-1003. [CrossRef] [PubMed]

3. Bassuk, E.L.; Buckner, J.C.; Perloff, J.N.; Bassuk, S.S. Prevalence of mental health and substance use disorders among homeless and low-income housed mothers. Am. J. Psychiatry 1998, 155, 1561-1564. [CrossRef] [PubMed]

4. Tinland, A.; Boyer, L.; Loubière, S.; Greacen, T.; Girard, V.; Boucekine, M.; Fond, G.; Auquier, P. Victimization and posttraumatic stress disorder in homeless women with mental illness are associated with depression, suicide, and quality of life. Neuropsychiatr. Dis. Treat. 2018, 14, 2269-2279. [CrossRef] 
5. Husky, M.M.; Lépine, J.-P.; Gasquet, I.; Kovess-Masfety, V. Exposure to Traumatic Events and Posttraumatic Stress Disorder in France: Results From the WMH Survey. J. Trauma. Stress 2015, 28, 275-282. [CrossRef]

6. Bender, K.; Brown, S.M.; Thompson, S.J.; Ferguson, K.M.; Langenderfer, L. Multiple victimizations before and after leaving home associated with PTSD, depression, and substance use disorder among homeless youth. Child Maltreat. 2015, 20, 115-124. [CrossRef]

7. Salem, B.E.; Brecht, M.-L.; Ekstrand, M.L.; Faucette, M.; Nyamathi, A.M. Correlates of physical, psychological, and social frailty among formerly incarcerated, homeless women. Health Care Women Int. 2019, 40, 788-812. [CrossRef]

8. McFarlane, A.C. Posttraumatic stress disorder: A model of the longitudinal course and the role of risk factors. J. Clin. Psychiatry 2000, 61 (Suppl. 5), 15-20.

9. Observatoire National de la Pauvreté et de L'exclusion Sociale. Le Rapport de l'Observatoire National de la Pauvreté et de L'exclusion Sociale 2009-2010-Bilan de 10 ans D'observation de la Pauvreté et de L'exclusion Sociale à L'heure de la Crise; Direction de L'information Légale et Administrative: Paris, France, 2010.

10. An Overview of Housing Exclusion in Europe, 2015. FEANTSA. Available online: https://www. feantsaresearch.org/en/report/2018/03/21/the-second-overview-of-housing-exclusion-in-europe-2017 (accessed on 21 March 2018).

11. Fazel, M.; Wheeler, J.; Danesh, J. Prevalence of serious mental disorder in 7000 refugees resettled in western countries: A systematic review. Lancet 2005, 365, 1309-1314. [CrossRef]

12. Steel, Z.; Silove, D.; Chey, T.; Bauman, A.; Phan, T.; Phan, T. Mental disorders, disability and health service use amongst Vietnamese refugees and the host Australian population. Acta Psychiatr. Scand. 2005, 111, 300-309. [CrossRef]

13. Turner, S.W.; Bowie, C.; Dunn, G.; Shapo, L.; Yule, W. Mental health of Kosovan Albanian refugees in the U.K. Br. J. Psychiatry J. Ment. Sci. 2003, 182, 444-448. [CrossRef]

14. Lindert, J.; von Ehrenstein, O.S.; Priebe, S.; Mielck, A.; Brähler, E. Depression and anxiety in labor migrants and refugees-A systematic review and meta-analysis. Soc. Sci. Med. 2009, 69, 246-257. [CrossRef] [PubMed]

15. Fortuna, L.R.; Porche, M.V.; Alegria, M. Political violence, psychosocial trauma, and the context of mental health services use among immigrant Latinos in the United States. Ethn. Health 2008, 13, 435-463. [CrossRef] [PubMed]

16. Kaltman, S.; Green, B.L.; Mete, M.; Shara, N.; Miranda, J. Trauma, Depression, and Comorbid PTSD/Depression in a Community Sample of Latina Immigrants. Psychol. Trauma Theory Res. Pract. Policy 2010, 2, 31-39. [CrossRef] [PubMed]

17. Aragona, M.; Pucci, D.; Mazzetti, M.; Geraci, S. Post-migration living difficulties as a significant risk factor for PTSD in immigrants: A primary care study. ResearchGate 2012, 9, e7525-e7528. [CrossRef]

18. Carswell, K.; Blackburn, P.; Barker, C. The relationship between trauma, post-migration problems and the psychological well-being of refugees and asylum seekers. Int. J. Soc. Psychiatry 2011, 57, 107-119. [CrossRef]

19. Li, S.S.Y.; Liddell, B.J.; Nickerson, A. The Relationship Between Post-Migration Stress and Psychological Disorders in Refugees and Asylum Seekers. Curr Psychiatry Rep. 2016, 18, 82. [CrossRef]

20. Vandentorren, S.; Le Méner, E.; Oppenchaim, N.; Arnaud, A.; Jangal, C.; Caum, C.; Vuillermoz, C.; Martin-Fernandez, J.; Lioret, S.; Roze, M.; et al. Characteristics and health of homeless families: The ENFAMS survey in the Paris region, France 2013. Eur. J. Public Health 2016, 26, 71-76. [CrossRef]

21. Hill, R.P. Homeless Children: Coping with Material Losses. J. Consum. Aff. 1992, 26, 274-287. [CrossRef]

22. Coates, J.; McKenzie-Mohr, S. Out of the Frying Pan, into the Fire: Trauma in the Lives of Homeless Youth Prior to and during Homelessness. J. Sociol. Soc. Welf. 2010, 37, 65.

23. Seng, J.S.; Clark, M.K.; McCarthy, A.M.; Ronis, D.L. PTSD and physical comorbidity among women receiving Medicaid: Results from service-use data. J Trauma. Stress 2006, 19, 45-56. [CrossRef] [PubMed]

24. Twamley, E.W.; Allard, C.B.; Thorp, S.R.; Norman, S.B.; Hami Cissell, S.; Hughes Berardi, K.; Grimes, E.M.; Stein, M.B. Cognitive impairment and functioning in PTSD related to intimate partner violence. J. Int. Neuropsychol. Soc. 2009, 15, 879-887. [CrossRef] [PubMed]

25. Cougle, J.R.; Resnick, H.; Kilpatrick, D.G. PTSD, depression, and their comorbidity in relation to suicidality: Cross-sectional and prospective analyses of a national probability sample of women. Depress. Anxiety 2009, 26, 1151-1157. [CrossRef] 
26. Katrinli, S.; Stevens, J.; Wani, A.H.; Lori, A.; Kilaru, V.; van Rooij, S.J.H.; Hinrichs, R.; Powers, A.; Gillespie, C.F.; Michopoulos, V.; et al. Evaluating the impact of trauma and PTSD on epigenetic prediction of lifespan and neural integrity. Neuropsychopharmacology 2020. online ahead of print. [CrossRef]

27. PTSD and Social Functioning. A three year prospective study. Soc. Psychiatry Psychiatr. Epidemiol. 1989, $24,127-133$.

28. Summerfield, D. A critique of seven assumptions behind psychological trauma programmes in war-affected areas. Soc. Sci. Med. 1999, 48, 1449-1462. [CrossRef]

29. Wright, J.; Rubin, B.A. Les sans-domicile aux États-Unis. Leçons tirées de quinze années de recherche. Soc. Contemp. 1998, 30, 35-66. [CrossRef]

30. Leon, L.; Jauffret-Roustide, M.; Le Strat, Y. Design-based inference in time-location sampling. Biostat. Oxf. Engl. 2015, 16, 565-579. [CrossRef]

31. Sheehan, D.V.; Lecrubier, Y.; Sheehan, K.H.; Amorim, P.; Janavs, J.; Weiller, E.; Hergueta, T.; Baker, R.; Dunbar, G.C. The Mini-International Neuropsychiatric Interview (M.I.N.I.): The development and validation of a structured diagnostic psychiatric interview for DSM-IV and ICD-10. J. Clin. Psychiatry 1998, 59 (Suppl. 20), $22-33$.

32. Seedat, S.; Stein, M.B. Post-traumatic stress disorder: A review of recent findings. Curr. Psychiatry Rep. 2001, 3, 288-294. [CrossRef] [PubMed]

33. Martin-Fernandez, J.; Grillo, F.; Parizot, I.; Caillavet, F.; Chauvin, P. Prevalence and socioeconomic and geographical inequalities of household food insecurity in the Paris region, France, 2010. BMC Public Health 2013, 13, 486. [CrossRef] [PubMed]

34. Radimer, K.L. Measurement of household food security in the USA and other industrialised countries. Public Health Nutr. 2002, 5, 859-864. [CrossRef] [PubMed]

35. Kessler, R.C.; Ustu "n, T.B. The World Mental Health (WMH) Survey Initiative Version of the World Health Organization (WHO) Composite International Diagnostic.Interview (CIDI). Int. J. Methods Psychiatr. Res. 2004, 13, 93-121. [CrossRef] [PubMed]

36. Jayasekera, H.; Carter, G.; Clover, K. Comparison of the Composite International Diagnostic interview (CIDI-Auto) with clinical diagnosis in a suicidal population. Arch. Suicide Res. Off. J. Int. Acad. Suicide Res. 2011, 15, 43-55. [CrossRef]

37. Robins, L.N.; Wing, J.; Wittchen, H.U.; Helzer, J.E.; Babor, T.F.; Burke, J.; Farmer, A.; Jablenski, A.; Pickens, R.; Regier, D.A. The Composite International Diagnostic Interview. An epidemiologic Instrument suitable for use in conjunction with different diagnostic systems and in different cultures. Arch. Gen. Psychiatry 1988, 45, 1069-1077. [CrossRef]

38. Zou, G. A modified poisson regression approach to prospective studies with binary data. Am. J. Epidemiol. 2004, 159, 702-706. [CrossRef]

39. Whitbeck, L.B.; Armenta, B.E.; Gentzler, K.C. Homelessness-Related Traumatic Events and PTSD Among Women Experiencing Episodes of Homelessness in Three U.S. Cities. J. Trauma. Stress 2015, 28, 355-360. [CrossRef]

40. Chan Chee, C.; Gourier-Fréry, C.; Guignard, R.; Beck, F. [The current state of mental health surveillance in France]. Sante Publique 2011, 23 (Suppl. 6), S13-S29.

41. Roze, M.; Vandentorren, S.; Vuillermoz, C.; Chauvin, P.; Melchior, M. Emotional and behavioral difficulties in children growing up homeless in Paris. Results of the ENFAMS survey. Eur. Psychiatry 2016, 38, 51-60. [CrossRef]

42. O'Donnell, M.L.; Creamer, M.; Pattison, P. Posttraumatic stress disorder and depression following trauma: Understanding comorbidity. Am. J. Psychiatry 2004, 161, 1390-1396. [CrossRef]

43. Breslau, N.; Davis, G.C.; Peterson, E.L.; Schultz, L. Psychiatric sequelae of posttraumatic stress disorder in Women. Arch. Gen. Psychiatry 1997, 54, 81-87. [CrossRef] [PubMed]

44. Porter, M.; Haslam, N. Predisplacement and postdisplacement factors associated with mental health of refugees and internally displaced persons: A meta-analysis. JAMA 2005, 294, 602-612. [CrossRef] [PubMed]

45. Knipscheer, J.W.; Kleber, R.J. The relative contribution of posttraumatic and acculturative stress to subjective mental health among Bosnian refugees. J. Clin. Psychol. 2006, 62, 339-353. [CrossRef]

46. Chu, T.; Keller, A.S.; Rasmussen, A. Effects of post-migration factors on PTSD outcomes among immigrant survivors of political violence. J. Immigr. Minor. Health 2013, 15, 890-897. [CrossRef] 
47. Coker, A.L.; Smith, P.H.; Thompson, M.P.; McKeown, R.E.; Bethea, L.; Davis, K.E. Social support protects against the negative effects of partner violence on mental health. J. Womens Health Gend. Based Med. 2002, 11, 465-476. [CrossRef] [PubMed]

48. Kawachi, I.; Berkman, L.F. Social ties and mental health. J. Urban Health Bull. N. Y. Acad. Med. 2001, 78, 458-467. [CrossRef] [PubMed]

49. Strohschein, L.; McDonough, P.; Monette, G.; Shao, Q. Marital transitions and mental health: Are there gender differences in the short-term effects of marital status change? Soc. Sci. Med. 2005, 61, 2293-2303. [CrossRef] [PubMed]

50. Hondius, A.J.; van Willigen, L.H.; Kleijn, W.C.; van der Ploeg, H.M. Health problems among Latin-American and middle-eastern refugees in The Netherlands: Relations with violence exposure and ongoing sociopsychological strain. J. Trauma. Stress 2000, 13, 619-634. [CrossRef]

51. Toscani, L.; Deroo, L.A.; Eytan, A.; Gex-Fabry, M.; Avramovski, V.; Loutan, L.; Bovier, P. Health status of returnees to Kosovo: Do living conditions during asylum make a difference? Public Health 2007, 121, 34-44. [CrossRef]

52. Hartzell, G.; Stenson, A.F.; van Rooij, S.J.H.; Kim, Y.J.; Vance, L.A.; Hinrichs, R.; Kaslow, N.; Bradley, B.; Jovanovic, T. Intergenerational effects of maternal PTSD: Roles of parenting stress and child sex. (published online ahead of print, 9 January 2020]. Psychol. Trauma. 2020. [CrossRef]

53. Samuelson, K.W.; Wilson, C.K.; Padrón, E.; Lee, S.; Gavron, L. Maternal PTSD and Children's Adjustment: Parenting Stress and Emotional Availability as Proposed Mediators. J. Clin. Psychol. 2017, 73, 693-706. [CrossRef] [PubMed]

54. Christie, H.; Hamilton-Giachritsis, C.; Alves-Costa, F.; Tomlinson, M.; Halligan, S.L. The impact of parental posttraumatic stress disorder on parenting: A systematic review. Eur. J. Psychotraumatol. 2019, 10, 1550345. [CrossRef] [PubMed]

55. Kobel, F.; Morawa, E.; Erim, Y. Effectiveness of Inpatient Psychotherapy for Patients With and Without Migratory Background: Do They Benefit Equally? Front. Psychiatry 2020, 11, 542. [CrossRef] [PubMed]

56. Breslau, N.; Kessler, R.C. The stressor criterion in DSM-IV posttraumatic stress disorder: An empirical investigation. Biol. Psychiatry 2001, 50, 699-704. [CrossRef]

(C) 2020 by the authors. Licensee MDPI, Basel, Switzerland. This article is an open access article distributed under the terms and conditions of the Creative Commons Attribution (CC BY) license (http://creativecommons.org/licenses/by/4.0/). 